\title{
Selecting Literary Texts for Language Learning
}

Chris Lima

\section{Abstract}

In many English language learning and teaching contexts the absence of literary texts, such as graded readers, short stories and poems, still seems to be the norm. This article looks briefly at the some more recent historical positions regarding the use of literature in ELT, and then discusses how the inclusion of creative reading material may foster the development of reading and critical thinking skills.

Key words: Literature, language input, poetic language, web 2.0

\section{Introduction}

In future years, the absence of imaginative content in language teaching will be considered to have marked a primitive stage of the discipline. (McRae, 1991 p. vii)

In many English language learning and teaching contexts the absence of literary texts, such as graded readers, short stories and poems, still seems to be the norm. Where textbooks are used, and depending on the title adopted, sometimes extracts of a novel or a short poem may timidly make their way among a majority of non-fictional texts, such as extracts of newspaper articles, samples of travel brochures, or content from webpages. Where teachers themselves select and/or design their materials, it is up to individuals to decide whether literature will be somehow included in the course syllabus and/or particular lesson plans. If so, teachers then have to decide on which texts to include, for what purposes to use them, and what activities will be done to explore the texts and promote language development. Not easy tasks, by all means. The difficulties of selecting material alone may be significant enough to put teachers off the enterprise of bringing literature to the language classroom altogether.

This article looks briefly at the some more recent historical positions regarding the use of literature in ELT, and then discusses how the It concludes proposing some criteria for text selection and some suggestions on how to use these texts in conjunction with other textual forms and media.

\section{The Place of Literature in ELT}

English language teaching has been through a series of historical phases and so have teachers who try to apply in the classrooms the methodological principles that are promoted by linguists, researchers and materials writers. From the 1950s to early 1980s English language teaching was dominated by discourses that advanced very pragmatic approaches to language, where communicative competence and specific practical and functional purposes were the main concerns. Approaches focused on using language in social situations and syllabuses were designed along 'functional/notional lines' (Brumfit, 1985 p. 6). There was little space for creativity and literature in such language teaching context. In the last decades of the twentieth century and the beginning of the twenty-first things began to change and literature started to be considered as a potential source for language development (Hall, 2005), perhaps even because teachers on the ground always suspected that there was something wrong in neglecting such a rich source of language input (Lima, 2005). However, literature still has to carve a niche for itself in mainstream language teaching materials. What McRae predicted in 1991 is still far from coming into being twenty years later. 


\section{Exploring Texts}

Voices speaking against the inclusion of literature in language courses usually resort to the wellknown argument that most literary texts bring vocabulary that is not relevant to language learners and some go to lengths to say that we do not really want twenty-first century English speakers to go around the streets uttering 'outdated poetic' language. Such argument barely stands the most basic scrutiny. First of all, even though there is some truth in it, some of what is perceived as outdated poetic language is just language that is not included in ELT textbooks for the sake of grading and simplification, but is actually language that people would normally encounter in authentic texts, literary or not (Brumfit and Carter, 1986 pp. 5-15). Secondly, lexical appropriacy objections can easily be overcome with the teacher's careful selection of texts and judicious task designing (Collie and Slater, 1987).

As a teacher what I search for are texts which (a) engage affectively, (b) challenge cognitively, (c) promote language awareness, and (d) help learners to reflect critically about and respond imaginatively to the world where they live.

Derrida (1976, p. 157) states that 'reading and interpretation are not merely acts of reproducing what writers express in a text'. For him, reading is actually an act of producing a new text, since authors cannot entirely dominate and control their creation and be totally aware of the systems and laws embedded in their own discourse. In other words, the meaning of a text is also created by its reader. There are very practical implications that spring up from this view of reading. If we understand the act of reading as an act of meaning construction, we should create opportunities in the classroom where learners can engage with texts in a critical, open-minded and creative way in order to realise that interpretation and meaning are not fixed givens. Moreover, we should propose activities which help learners to realise that the 'meaning' of a text is the result of a multiplicity of voices and influences (Bakhtin, 1981 pp. 2623 ), including the ones they bring themselves to the reading process. If we adopt such approach, grammar and vocabulary cease to be only a matter of syntax, semantics and morphology to become a complex network of ideas, symbols and meanings (Pinker, 1994). Language thus ceases to be the territory where learners exercise purely analytical processes to become the territory where language and meaning are discovered and construed.

Such views would lead us to propose tasks which give learners the opportunity to explore different layers of meaning and create their own readings using them as starting point for an examination of various realities and contexts. This could then be followed by an analysis of how language creates meaning in the text (McRae, 1991), moving towards a broader exploration of different readings. Learners and teachers would, therefore, be both involved in a reading of texts that aim to develop language and reading skills through critical thinking process.

\section{Criteria for Text Selection}

Possible criteria for text selection, for classroom and extensive reading (Waring, 2008), could include some of the principles advanced by Prowse (2002, pp. 142-4) for the selection of extensive reading material:

Choice: as far as possible, let your students choose the test they want to read. There is plenty of English language learner literature, also called graded readers, available from international ELT publishers -from adaptations of classics to original stories (http://www.erfoundation.org/erf/). Even if your school library is limited, offering students a shortlist at least gives them a certain degree of choice. Besides that, there is plenty of free copyright material available on the Internet (see links below). Deciding for others what they would read is hardly ever something we would do in real life to our family and friends, and the same should apply to our learners. What we can do is to suggest and recommend reading material based on what is available to us and what we considered culturally and linguistically appropriate.

Ease: finding a text with the right language level is crucial. It should neither be too difficult that students cannot infer the meaning of particular lexical items and are forced to look up words too frequently; nor too easy that there is no challenge and no vocabulary gain. Teachers' own language awareness and knowledge of their students' 
proficiency levels are ultimately the best guides in making a decision.

Texts to engage with and react to: texts should engage readers cognitively and affectively (Elliot, 1990). Nothing is more effective in killing the joy of reading than a boring text. However, what teachers see as interesting (or boring) may not necessarily be the same for the students - choice is again an important element.

No tests and no comprehension questions: this is a quite controversial issue and it demands a far more extensive and serious discussion than the one permitted by the limits of this article. My own position is that there are other ways of assessing students' response to texts, as well as the language development they achieved by reading them, than formal tests and comprehension questions. Some options may include follow-up writing, classroom presentations and face-to-face or online discussions.

Teachers' participation: I believe teachers, as parents and politicians, should lead by example. Asking your students to read literature when you do not read it yourself can no only undermine your reputation and authority, but also create some quite embarrassing situations. Besides that, students would probably feel much more motivated if they can engage with the teacher in a real and meaningful discussion about the texts they are reading.

Besides the list above, we should also consider Brumfit's criteria for text selection (1985: 109) which relates to suitable linguistic level, 'cultural and social expectations of different groups of learners,' and length of the text. Imagination and creativity should also be our concerns. Literary texts, and the tasks based on them, should help learners to activate and exercise their imagination. There is plenty of imaginative material that could be explored in conjunction with literary texts, such as:

Visual arts: paintings and photographs can be used as both warm-up or follow-up activities. They can provide memorable material with strong visual appeal and impact (Benton, 1992)

Dramatic arts and music: kinaesthetic and auditory learners may benefit a lot from activities which include classroom or recorded performance of short scenes of a play, songs or poems (Maley and Duff, 2005). These activities may also provide good opportunities for collaborative learning and for working on pronunciation.

Web2 tools: when access to the Internet is possible, the use of wikis, blogs, discussion forums and web quests can broaden the experience of a text and be used to promote collaborative writing, creative writing, exchange of ideas and contextualisation of literature works.

\section{Conclusion}

This paper reviewed some criteria for the selection of literary texts to be used in English language teaching and suggested some ways of combining texts with other forms of media, such as visual and dramatic arts, music and the new interactive online tools.

It calls for the inclusion of language learner literature, short stories and poems in English language teaching order to bring to our teaching practice and classroom experience the creative exploration of language, meaningful and creative content and a habit of reading and thinking that tries to cater for a generation of language learners who would be able to critically and creatively make meaning of the texts they read.

Chris Lima is a Doctoral Student at the Centre for Research in Education and Educational Technology, Open University, UK. Her areas of interest include Critical Literacy, Extensive Reading and Literature in ELT. She is the coordinator of the British Council Teaching English ELT e-Reading Group, a board member of the Extensive Reading Foundation and a committee member of the IATEFL, Literature, Media and Literatue SIG.

\section{References}

Bakhtin, M. M. (1981). The dialogic imagination. Austin, TX: University of Texas Press.

Benton, M. (1992). Literature teaching and the visual arts. Buckingham: Open University Press.

Brumfit, C. (1985). Language and literature teaching: From practice to principle. Oxford: Pergamon Press.

Brumfit, C. \& Carter, R. (1986). Literature and language teaching. Oxford: Oxford University Press. 
Collie, J. \& Slater, S. (1987). Literature in the language classroom. Cambridge: Cambridge University Press.

Derrida, J. (1976). The exorbitant question of method. In Spivak, G. C. Of Grammatology. Baltimore, MD: John Hopkins University Press.

Elliot, R. (1990). Encouraging reader-response to literature in ESL situations. ELT Journal, $44 / 3$.

Hall, G. (2005). Literature in language education. Basingstoke: Palgrave Macmillan.

Lima, C. (2005). Is the rest silence? IATEFL Voices, 186.
Maley, A. \& A. Duff (2005). Drama techniques. Cambridge: Cambridge University Press.

McRae, J. (1991). Literature with a small ' $l$ '. London: Macmillan.

Pinker, S. (1994). The language instinct. London: Penguin.

Prowse, P. (2002). Top ten principles for teaching extensive reading: A response. Reading in a Foreign Language, 14/2.

Waring, R. (2008). Why extensive reading should be an indispensable part of all language programmes. Extensive Reading Foundation. Retrieved from http://erfoundation.org/ node/18 Accessed 18 Nov 2008.

\section{Useful Links}

\section{Online Texts}

The Project Gutenberg

Black Cat Poems

Classic Reader

The Guardian Saturday Poem

Images and Paintings

The National Gallery

National Galleries of Scotland

Google Images http://www.gutenberg.org

http://www.blackcatpoems.com/index.html

http://www.classicreader.com/

http://www.guardian.co.uk/books/series/saturdaypoem

http://www.nationalgallery.org.uk/

http://www.nationalgalleries.org/

http://www.google.co.uk/

\section{Supporting websites for English Language Teachers}

- The ELT e-Reading Group at the BBC/British Council Teaching English http://www.teachingenglish.org.uk/group/elt-e-reading-group

- The Extensive reading Foundation http://www.erfoundation.org/erf/

- IATEFL Literature Media and Cultural Studies SIG http://lmcs.iatefl.org/ 